\title{
Opinión
}

\section{Avances y contradicciones (paradojas) en relación con las causas del cáncer}

\author{
(Advances and Contradictions in Relation to the Causes of Cancer)
}

Juan Jaramillo Antillón

\section{Resumen:}

La importancia del cáncer, en el ámbito mundial, reside en que esta enfermedad ocupa, según la Organización Mundial de la Salud, el primer lugar como causa de muerte, seguido de cerca por las enfermedades cardiovasculares. En Costa Rica, fallecieron 16700 personas en el 2006, de las cuales 3751 fueron por cáncer. Ahora sabemos que los mismos genes que producen la vida, pueden provocar cáncer y causarnos la muerte, cuando son alterados por mutágenos del ambiente o en pocos casos lesionados antes de nacer el niño. Se conoce que ciertos genes de crecimiento y división celular normal al alterarse, producen cáncer por su presencia (oncógenos) y otros, los genes que regulan o frenan la división celular normal, si están ausentes o lesionados, dan también lugar a la aparición del cáncer, todo ello debido a que producen enzimas y proteínas que alteran la función de esos genes. Por lo tanto, no hay una sola causa que provoque un cáncer, sino que existen múltiples factores que evitan o aceleran la aparición de un tumor.

Descriptores: Causas, cáncer, genética

\section{Abstract:}

The importance of cancer worldwide derives from de fact that it is the number one cause of death, closely followed by cardio-circulatory diseases, according to the WHO. In Costa Rica, during 2006, 16700 people died, 3751 from cancer, corresponding to $23 \%$ of the total deaths. With the breakthrough of the genetic code in the last few years, the advancements in the causes of cancer have centered in the genes and the proteins they produce. Today we know that the same genes that create life may provoke cancer and death, when they are altered by mutagens acquired in the

Catedrático de la Escuela de Medicina y Profesor Emérito de la UCR y Presidente de la Academia Nacional de Medicina de 1996 a 1999, Ministro de Salud de 1982 a 1986.

ISSN 0001-6002/2010/52/4/246-254

Acta Médica Costarricense, (C2010

Colegio de Médicos y Cirujanos environment or in a few cases damaged before birth. It is known that certain growth and normal cell division genes, when altered produce cancer (oncogenes), others, such as the genes that regulate or stop normal cell division, if absent or damaged, may also produce cancer, all due to the production of enzymes and proteins that alter the function of such genes and as long as they are not repaired by the repairing genes that are constantly at work preventing the apparition of a tumor. But, there is not one only cause that provokes cancer, there are several others factors that prevent or accelerate the apparition of a tumor.

Keywords: Causality, cancer, genetics

Recibido: 23 de febrero de 2010

Aceptado: 10 de agosto de 2010

Según la Organización Mundial de la Salud (OMS), el cáncer fue la primera causa de muerte en el mundo, con 7.9 millones por año, en el $2007 .{ }^{1}$ Provoca el 13\% anual de las muertes y lo triste es que por lo menos, un $30 \%$ son prevenibles. Los principales tumores en causar la muerte son, en su orden el cáncer del pulmón con 1.3 millones de muertes; el de estómago, con casi 900 mil; hígado y colon con más de 650 mil y mama con 502 mil. ${ }^{1}$

En Costa Rica, en el año 2006, fallecieron, en total, por enfermedades y accidentes 16.760 personas. Por cáncer 3751 (22.38\% del total), lo que constituye un promedio de más de 10 muertes diarias, y por problemas cardiocirculatorios 4845, para un total entre ambos, de 8576, o sea, el $51.15 \%$ de las muertes. ${ }^{2-5} \mathrm{El}$ cáncer aumentó en frecuencia, un $30.9 \%$ en los últimos 10 años y la mortalidad creció en un $8 \%$. En ese tiempo, el cáncer de estómago disminuyó en un $25 \%$ y en la mortalidad en un $44 \%$. El de próstata aumentó un $60 \%$, y el de mama y colon un $32 \%$. $^{2-6}$

En el país, la esperanza de vida promedio es de 79 años (mujeres 81.4 y hombres 76.9) la segunda en América. Igual a la de Estados Unidos y solo por debajo de Canadá con 81 años, eso explica la alta frecuencia de muertes por cáncer y problemas cardiovasculares. En la revista Scientific American ${ }^{7}$ se señaló, que en los Estados Unidos, un estudio prospectivo 
realizado en el año 2007 sugirió que, el 39\% de los hombres y el $45 \%$ de las mujeres tendrán algún tipo de cáncer durante su vida. El cáncer afecta no solo a los seres humanos sino también, a los animales y a las plantas, lo que parece confirmar que son trastornos en el ADN (que es similar químicamente hablando en los tres grupos), donde está el inicio del mismo. Se han descubierto tumores óseos en dinosaurios de más de 100 millones de años de antigüedad. ${ }^{6}$ No es raro que nuestras mascotas, perros y gatos mueran por cáncer. ${ }^{8}$

\section{Historia}

Se han encontrado huellas de cáncer en los huesos de momias del antiguo Egipto, que datan de 3000 años a. C. En el Papiro de Edwin Smith de más de 3.600 años de antigüedad, se relatan 8 casos de cáncer de la mama, uno ulcerado y tratado mediante la extirpación por cauterización. ${ }^{6,9}$

Es importante conocer el origen del vocablo cáncer. La palabra carcinoma se le atribuye al padre de la medicina Hipócrates y luego él, o su escuela, emplearon la palabra griega karkino (cangrejo), como equivalente a cáncer, en alusión a su forma de propagarse, semejando las patas de un cangrejo. Desde entonces, ese término se empleó mundialmente para calificar a los tumores malignos. ${ }^{9,10}$

En 1775, Sir Percival Potts, cirujano inglés, señaló la asociación que existía entre el cáncer del escroto y la presencia de polvo de carbón en la ropa y la piel de los deshollinadores de chimeneas de Londres, y responsabilizó al carbón como causa de ese cáncer. De esta manera, se reconoció la asociación causa-efecto de una sustancia que provoca un tumor. A partir de aquí, se inició la búsqueda de agentes causantes de las diferentes formas de tumores. ${ }^{6}$

El alemán Dr. Johannes Muller, en 1838, hizo la observación microscópica que los tumores estaban compuestos de células desorganizadas y anormales. Pocos años después, el cirujano francés Henri Francois le Dran indicó que el cáncer se diseminaba inicialmente a los nódulos linfáticos locales y de ahí pasaba a la circulación general. El patólogo alemán Rudolf Virchow en 1870, señaló que toda célula proviene de una célula anterior; hoy ese concepto lo aplicamos a las células sanas como a las malignas. Su alumno, Julios Conhein en 1877 propuso que restos embrionarios de células indiferenciadas persisten como tales en las personas desde que nacen, esperando el impulso que haga que muestren su capacidad ilimitada de crecimiento en algún momento de su vida. ${ }^{6}$

En el año 1911, el Dr. Peyton Rous logró aislar un virus del sarcoma de los pollos y lo transmitió a otros animales, mostrando así que un virus era capaz de transmitirse y producir tumores. Posteriormente, Denis Burkitt, sospechó que un linfoma de la mandíbula de niños africanos era producido por un virus, y Epstein y Barr, confirmaron que era un herpes virus, que además, provocaba el carcinoma nasofaríngeo en Asia.
A continuación, planteo una serie de paradojas que resultan relevantes para conocer más en relación con la enfermedad objeto de este artículo.

\section{Paradojas}

Paradoja 1. Algunos estudiosos del cáncer, creen que las "Stem Cells" (células madres o primitivas) que nos dan la vida, pueden tener participación importante en la aparición de tumores y causarnos la muerte. Hay dos grupos de células madre:

1- Células madres embrionarias, se forman e inician su acción entre los 4 y 6 días cuando el óvulo es fertilizado y tienen una capacidad infinita para multiplicarse $y$ especializarse y dan origen a los 220 tipos de células que forman todos los tejidos y los órganos en el embrión y el feto. Podrían ser las primeras en afectarse si por alguna causa sus genes sufren mutaciones en un tejido. ${ }^{11}$

2- Las células madres adultas (se han reconocido diversos tipos), están presentes en los tejidos del cuerpo humano, pero no se expresan o funcionan normalmente excepto, en la piel, médula ósea y aparato digestivo, donde ayudan a regenerar las células en tejidos de continuo desgaste. ${ }^{12-14}$

Las alteraciones que afectan los genes de los cromosomas sexuales (mutaciones embrionarias) se heredarán, y si son mutaciones que afectan genes de los cromosomas no sexuales, de células madres adultas u otro tipo de células después del nacimiento, se califican como mutaciones somáticas. El 90\% de los cánceres muestran mutaciones somáticas (adquiridas). El resto son mutaciones germinales o de ambos tipos. ${ }^{15}$ Se han identificado grupos de estas células madres mutadas en una proporción que varía entre $0.1 \%$ a $25 \%$ formando parte de los diferentes tumores como melanomas, mielomas, la leucemia aguda, y los cánceres de la próstata, mama y cerebro. Otros creen que por lo menos podrían ser la causa de las recaídas y de las metástasis. ${ }^{11,16-19}$ La Dra. Eva Hernando, del departamento de Patología de la Universidad de Nueva York, considera correcta la hipótesis que un tumor depende de sus células madres para desarrollarse y seguir creciendo. ${ }^{11,13}$ Sin embargo, esta teoría de las células madres generadoras del cáncer es controversial y no es aceptada por diversos patólogos, quienes consideran que algunos grupos de células malignas se indiferencian tanto al formar tumores, que semejan células embrionarias, de ahí la confusión.

Lo que sí está ampliamente aceptado es que el cáncer tiene un inicio común en cambios o mutaciones de los genes de una célula. Sin embargo, a pesar de ello, no se habla de cáncer en singular, sino de cánceres en plural porque, se han encontrado más de 200 tipos diferentes de cánceres, afectando a todos y cada uno de los tejidos y órganos del cuerpo e incluso, pueden observarse diferentes tipos histológicos en un mismo tejido, con diferentes etiologías y 
si se califican en subgrupos se puede hablar casi de 500 tipos de cáncer. ${ }^{20}$

La variación en la frecuencia de diferentes tipos de cáncer se debe a la variación de diversos aspectos que se relacionan con su generación o prevención. Entre los factores que pueden influenciar esta variación están los que se citan en la caja de texto 1 .

En la actualidad, se diagnostican más cánceres debido a que hay más población y la gente vive más tiempo. Hay más viejos y es sabido que muchos cánceres duran años para desarrollarse. La carcinogénesis, o sea, el proceso en que una célula normal se transforma en cancerosa suele durar unos 10 años en promedio, según datos del Instituto Nacional de Cáncer de Estados Unidos..$^{20-41}$

Hay más diagnósticos, con la aparición de nuevos marcadores tumorales (se usan 14) entre ellos, el antígeno prostático especifico, que con la ayuda de la biopsia, diagnostica tumores de la próstata. La mira está puesta en producir marcadores tumorales que nos indiquen que un tumor in situ, no progresará o que por el contrario, se volverá invasor. A la fecha, se han encontrado 7 genes capaces de producir este tumor prostático. ${ }^{24-42} \mathrm{El}$ antígeno carcinoembrionario, sirve para diagnosticar recidivas post cirugía de cáncer de colon, y otros. Además, se logran más diagnósticos tempranos, con la citología tipo Papanicolau para el cáncer del cuello uterino o la endoscopía del aparato digestivo para tumores de esófago, estómago o colon, incluso en estos, al detectar pólipos adenomatosos y al extirparlos se evitan cánceres posteriormente. También detectan tumores tempranos, las mamografías de diversos tipos y los ultrasonidos, los TAC y RMN.

Ahora sabemos que dentro de los 46 cromosomas del núcleo de cada célula tenemos 20 mil o más genes, y dentro de estos, hay un grupo de "genes claves" que pueden prevenir o dar un cáncer, ya sea que se mantengan sanos cumpliendo su función o si son alterados por mutágenos del ambiente. ${ }^{25-}$ ${ }^{27}$ Sabemos que solamente el $1.2 \%$ del ADN del núcleo de las células normales contiene los genes que nos dan la vida. El resto era considerado ADN chatarra; sin embargo, estudios recientes muestran que este ADN, supuestamente inútil, contiene ARN que ayuda al ARN mensajero producido o enviado por el ADN del núcleo, hacia los ribosomas del protoplasma con una orden para producir proteínas. ${ }^{28}$ ¿Quién sabe qué papel se le va a encontrar a este ADN chatarra en la prevención o aparición del cáncer en el futuro?

A manera de recapitulación diremos que los genes en estado normal, funcionan produciendo enzimas y proteínas para dar las células de los diferentes tejidos y órganos en el embrión y feto, y una vez que el niño nace y durante toda su vida, están activos y mantienen la función normal de las células de los diferentes órganos del cuerpo.
Por años se supuso que cada gen codificaba (producía) una proteína determinada para una función específica. Sin embargo, está demostrado que pueden producir varias proteínas ya sea en soledad o en unión con otros genes, esto dificulta conocer con exactitud, la acción que cada uno de ellos ejerce para producir una función en un órgano. A la fecha, se han descrito más de 700 proteínas, producidas por esos 20 mil genes y están en estudio otras 20 mil o más.

Paradoja 2. Los mismos genes que nos proporcionan la vida, si se alteran (mutan) por alguna causa, son capaces de provocarnos la muerte como veremos.

Paradoja 3. Parece increíble que los genes estén simplemente formados por moléculas de fosfatos, azúcares y de bases (adenina-timina-guanina y citocina). Visto así, cada cuerpo humano consiste en un sistema de interacción molecular que trabaja para un todo. Cada célula del cuerpo tiene una copia completa del genoma hecha de tres billones de pares de bases, las letras del alfabeto genético que contienen los 20 mil o más genes, que representan las instrucciones para operar las células, los tejidos, los órganos y el propio ser humano, con ayuda de los diferentes ARN y los aminoácidos del protoplasma..,10,27 Pareciera que en el fondo de la vida humana, hay solo química de átomos y moléculas y sus recombinaciones, y aunque parezca una fantasía, esos átomos son iguales a los que existen en la Tierra o en las estrellas. Por supuesto, el ser humano es más que la suma de átomos, moléculas y $A D N$, ya que al formarse el cerebro por acción de esos genes a través de millones de años, apareció la mente (el cerebro con sus funciones) que nos dio la capacidad de apreciar y razonar los sucesos del medio ambiente y responder a ellos, según nuestras necesidades.

\section{La teoría genética del cáncer}

Este planteamiento acepta que, diversas mutaciones o cambios en genes sanos con funciones claves durante el desarrollo y la división celular, pueden producir una célula cancerosa. Pero, se requiere además, que el mecanismo natural de bloqueo de mutaciones o el de reparación de genes y células esté alterado, ya que normalmente, todos los días y en todo momento, se reparan lesiones de los genes o de las células, causadas por sustancias ambientales. ${ }^{29,30}$ Aquí los genes de las "stem cells" de los tejidos, parecen participar activamente en algunos casos. ${ }^{31}$ Las investigaciones de dos décadas han revelado que las mutaciones son diferentes en uno u otro tumor, sugiriendo que existen vías y mecanismo diferentes en su origen. Es como si cada cáncer tuviera su propia huella digital. ${ }^{29,32}$ A lo anterior debe agregarse que aparezcan sustancias promotoras como el tabaco, virus, y otros, o que se pierda por alguna causa, la capacidad defensiva inmunológica local o general de una persona..$^{30,33}$

Paradoja 4. Todas las células del cuerpo de un adulto presentan mutaciones de diferentes tipos y no solo tumorales, 
que afectan a genes con diversas funciones bioquímicas acumuladas a través del tiempo, y son un riesgo propio al que todos los seres humanos estamos expuestos en la naturaleza. ${ }^{25,31}$ Pero la mayoría de las mutaciones del ADN son silenciosas y no tienen efecto alguno, ya que afectan partes del ADN sin genes, o aún afectándolos, estos pueden ser reparados.

Las mutaciones (o daños en los genes) más importantes son las que afectan genes que producen proteínas que regulan el ciclo celular. Jonker y Berns ${ }^{34}$ y Weinstein $^{31}$ señalan que parece haber una adición oncógena o dependencia de ciertos cánceres por uno o pocos genes que producen proteínas que tienen acciones importantes para dar malignidad. En el año 2008, el Dr. Elías Zerhouin, Director del National Institute of Health, señaló que se habían reconocido 350 mutaciones en genes humanos capaces de provocar cáncer por modificar la proteína que producen, debido a factores ambientales que afectaban a las personas. ${ }^{32}$ Esto representa apenas el 1.6\% de todos los genes que producen proteínas en el genoma, por lo que se espera que esta cifra siga creciendo. En animales de experimentación se han encontrado hasta 2.000 genes, cuyas alteraciones producen proteínas capaces de provocar un cáncer. ${ }^{35}$ En un grupo de 26 personas con cánceres del pulmón estudiados, se identificaron 188 mutaciones somáticas, afectando a 141 genes y 40 de esas mutaciones perjudicaban a genes que codificaban solamente una proteínkinasa. ${ }^{35}$ Según estudios del Hospital Henry Ford, en los cánceres de cabeza y cuello se han encontrado 231 genes alterados en sus células. ${ }^{23}$ Lawrence Loeb $^{36}$ señaló que en la génesis de un cáncer se presentan entre 10 mil a 100 mil mutaciones por célula. En una leucémica se han encontrado hasta 62.277 mutaciones y en cambio, en una célula de la piel sana del mismo individuo no se ven estas.

\section{Causas fundamentales de los diferentes tipos de cánceres}

Es relevante destacar que el $80 \%$ de los tumores se deben a cambios en los genes por mutaciones adquiridas causadas por sustancias carcinógenas ambientales ${ }^{37}$ como las radiaciones o tóxicos químicos. La prolongada exposición a los rayos del sol en especial, a los ultravioleta, está aumentando la aparición de cáncer de la piel y de melanomas en todo el mundo; ${ }^{3}$ igualmente, la exposición a radiaciones ionizantes (rayos X), a benceno (de gasolina), plaguicidas, tintes, tricloroetileno, agentes citotóxicos, Radón y carbón de las minas, y otros.

La Agencia Internacional para la Investigación del Cáncer ha analizado el potencial de 931 agentes para producir cáncer. ${ }^{3,22,38}$ Entre esos agentes destacamos los siguientes.

Virus: la Sociedad Americana de Cáncer considera que el $17 \%$ de los tumores están provocados por virus, ejemplo de estos el cáncer del hígado provocado por la hepatitis $\mathrm{B}$ y

\section{Caja de texto 1. Factores que influencian la variación en frecuencia de los diferentes tipos de cáncer}

1. Área geográfica, en relación con la buena o mala alimentación y las costumbres de una región, aparecen algunos tumores.

2. Edad, algunos tumores son más frecuentes en niños, pero la mayoría afecta a los adultos y a los ancianos debido a que los cánceres se deben a excesos de mutaciones de los genes que no pueden ser reparados a través de los años. Por ejemplo, el retinoblastoma, afecta sobre todo a niños debido a que las células de la retina dejan de multiplicarse cuando los infantes tienen 5 años, por eso es raro que aparezca en viejos. En cambio, en el cáncer de colon, sus células continúan replicándose hasta la vejez y tienen más oportunidad de volverse cancerosas, por ello hay más cáncer de colon. ${ }^{7}$

3. Sexo, algunos tumores afectan solo al sexo femenino como los de la matriz, los ovarios y la vulva. Otros, solo perjudican a los hombres: pene, testículo y próstata. $\mathrm{Y}$ otros, a ambos sexos, como estómago, colon y pulmón.

4. Etnia, ciertos tumores, como el que se desarrolla en la próstata, afectan más a personas de la raza negra. Aunque se aduce que esto sucede por factores ambientales, educativos y dietéticos.

5. Estado socio-económico y educación, a mayor pobreza y malas dietas y educación, parece haber mayor frecuencia de algunos tumores.

6. Factores de riesgo del ambiente, ocupación, alimentos y otros. Estar expuestos a ingerir o respirar, o el contacto con sustancias como el humo del tabaco, el asbesto e hidrocarburos policíclicos provoca el contraer ciertos tipos de cáncer. Las personas pobres que cocinan con carbón y leña durante años, pueden adquirir un cáncer del pulmón, ya que el humo de la combustión libera gran cantidad de hidrocarburos. ${ }^{21}$ También el cromo, benceno, plaguicidas, emisiones de diesel, y otros, promueven algunos tumores..$^{22} \mathrm{EI}$ ingerir exceso de grasa animal (carnes) diariamente, induce a la aparición de cáncer del colon. $80 \%$ de los cánceres del pulmón, cabeza y cuello se asocian al consumo del tabaco (fumado) por años, ya que sustancias de este producen trastornos del ADN y esto altera algunos genes. ${ }^{23}$

7. La obesidad y la falta de ejercicios y el abuso del licor constituyen factores de riesgo para la aparición de tumores.

C. Debemos aclarar que para los 300 millones de personas portadoras de la hepatitis B y 170 millones de la C, son muy pocas, si se hacen crónicas, las que terminan dando cáncer. ${ }^{10,39-41}$ Infecciones por relaciones sexuales al contraer el virus del papiloma humano; que forma parte de una gran familia viral que afecta al ser humano, algunos tipos como $16,18,31,33,35,45,52$ y 58 provocan cáncer, otros no. ${ }^{10,39}$ 


\section{Caja de texto 2. Mecanismos que participan para evitar o favorecer que se produzca un cáncer}

1. Una mejor defensa inmunológica en unos individuos más que en otros. ${ }^{44}$

2. Algunas personas tienen mejores mecanismos de reparación de genes o células que otros. El ADN es capaz de reparar errores de genes o células lesionados como por ejemplo, las causadas por irradiaciones. ${ }^{47}$

3. Mejores factores nutricionales. Buena alimentación con ingesta de antioxidantes como ya vimos.

4. Mayor exposición a factores de riesgo, como el tabaco, asbesto, el sol en exceso, inmunosupresión por un trasplante, tienen sida, y otros. ${ }^{18,37}$

5. Fallas en las defensas inmunológicas locales. La membrana de la célula tumoral produce antígenos que deberían ser reconocidos por las llamadas células dendriticas, macrófagos y neutrófilos de los linfáticos locales y destruirla o pedir su apoyo produciendo citoquinas como el interferón, las interleuquinas, y otros, mensajeros para que vengan los linfocitos $T$ matadores y los B con sus anticuerpos a acabarlas. Lamentablemente, al parecer, algunos tumores secretan factores que impiden a los macrófagos alertar a los linfocitos y a los anticuerpos debido a que no reconocen a la célula tumoral como extraña. .,33,58 $^{2,3}$

Sustancias en los alimentos, la presencia de nitritos en el agua o alimentos se convierten en nitrosaminas en el estómago.

Déficit de ingesta de ciertos nutrientes, como las vitaminas y minerales del tipo Vitamina $\mathrm{C}$, tocoferoles, betacarotenos, zinc, cobre, y otros, que actúan como antioxidantes, bloquean radicales libres como el oxígeno, donde hay procesos de cambio o destrucción celular provocan cáncer. ${ }^{3}$ Debemos insistir en que todos los autores señalan que son las vitaminas y minerales contenidos en los alimentos los que actúan así, no hay pruebas que en cápsulas o inyectadas den este resultado.

Sustancias inhaladas, provoca cáncer el humo del tabaco al fumar o al estar expuesto a aspirarlo aunque no se fume. El polvo del asbesto y las aflatoxinas dan cáncer del hígado. También el cromo, hidrocarburos, diesel, polvo de carbón, de madera, plomo, insecticidas y herbicidas (plaguicidas diversos), entre otros. ${ }^{22,38}$

Bacterias ingeridas, el Helicobacter pylori, como veremos más adelante. Parásitos, el Clonorchis sinensis se ha relacionado en Thailandia, con un colangiocarcinoma. El Schistoma haematobium en África, con cáncer de la vejiga urinaria. ${ }^{39,41}$

Hormonas, trastornos hormonales o el empleo de estas por mucho tiempo, pueden coadyuvar a producir cáncer del tiroides de tipo papilar por exceso de TSH, ciertos tumores ováricos provocan exceso de estrógenos e inducen a la aparición de cáncer del endometrio. Cáncer de la mama en quienes abusan de ingesta de estas hormonas para la menopausia. $^{42,43}$

Estrés, pueden acelerar su aparición los factores emocionales que causan angustia en forma continua (crónica), alteran la actividad endocrina e inmunitaria del organismo, y disminuye así, la producción de linfocitos $\mathrm{T}$, macrófagos y anticuerpos, por estimular la producción de ACTH y esta de cortisona, la cual baja la respuesta inmunitaria.

Sin embargo, el $15 \%$ de los tumores se deben a mutaciones espontáneas, Se han señalado zonas frágiles en ciertas partes del ADN o de los cromosomas, donde es más probable se produzcan mutaciones que conduzcan al cáncer. Entre más inestable se vuelve el genoma por mutaciones, hay más posibilidades de que aparezca un cáncer. Permanentemente, hay todo un complejo sistema de control y reparación del genoma. Sin embargo, algunos tipos de mutaciones escapan a la detección de las proteínas reparadoras. ${ }^{15,33,40,44} \mathrm{El} \mathrm{ADN}$ dañado, puede dar información errada al ARN mensajero (error al copiarse). Esto se debe a que se producen inesperadas reacciones espontáneas de tipo hidrólisis, que puede alterar las bases. También, durante el metabolismo se generan radicales libres como átomos de oxígeno o el nitrógeno que pueden lesionar al ADN. ${ }^{44} \mathrm{El}$ ARN mensajero puede equivocarse por sí y dar órdenes erróneas a los ribosomas y se produce una proteína diferente a la que se requería. Una translocación de un segmento de un cromosoma cerca de otro con un gen lesionado puede causar un cambio serio. En la Leucemia Mieloide Crónica aparece una mutación llamada "cromosoma Filadelfia" debido a que un segmento del cromosoma 9 se junta con uno del $22 \mathrm{y}$ aparece un gen mutante híbrido llamado "bcr", que a su vez, produce una proteína anormal que cambia las células mieloides normales en leucémicas. ${ }^{62} \mathrm{Un}$ fármaco llamado Gleevec $^{\circledR}$ inhibe la proteína alterada que se produce y se detiene la proliferación celular.

Finalmente, el 5\% de los cánceres son heredados o familiares. En estos casos se pueden heredar genes mutados de tipo de crecimiento y división desde el nacimiento, llamados por eso oncógenos o, al niño al nacer le falta un gen de tipo inhibidor o frenador de la división celular; como se ve en ciertos casos de cánceres de mama y colon. Por ejemplo: el $90 \%$ de las mujeres tienen sanos los dos genes BRCA 1 y 2 (el del padre y el de la madre). El BRCA 1 del cromosoma 17 y el BRCA 2 del cromosoma 13, que son los encargados de producir una proteína que impide el crecimiento desordenado y la excesiva división celular de las células mamarias. Pero, de un 5\% a $10 \%$ de las mujeres pueden heredar uno o los dos genes mutados y a la larga, producirse en ellas, un cáncer de la mama. ${ }^{28,45}$

Debe quedar claro que no hay una sola causa para producir un cáncer y que el problema es multifactorial.9,33 Una pregunta aún sin respuesta es: ¿cuántas mutaciones se necesitan para dar un cáncer? En algunos casos son pocas, 
Paradojas en relación con la causa del cáncer / Jaramillo-Antillón J

en la mayoría, muchas y durante muchos años, pero aún no es posible señalar eso con certeza para cada tumor maligno. ${ }^{10}$ "Al parecer", ya estamos en conocimiento de cuáles genes se deben alterar para que se produzca un tumor.

Paradoja 5. Sabemos que hay genes maestros (interruptores) que controlan las operaciones normales de muchos genes, activándolos o desactivándolos en las funciones que realizan constante-mente. Su función es crítica para que la célula se reproduzca correctamente y dirigen casi todas las funciones fundamentales del cuerpo. ${ }^{23,46,47} \mathrm{Sin}$ embargo, se le han calificado con el término de protooncógenos por que si un gen de estos muta, se produce un gen oncógeno. Ejemplos de esto incluyen los genes mycras-E2F1-E1A, y otros. Estos podrían en ciertos casos, hacer que la célula se divida continuamente sin parar o sea, existen genes de crecimiento y división celular, esos genes hacen que una célula normal se divida de una a un máximo de 50 a 70 veces, según el tipo de tejido al que pertenezca. Sería como un reloj biológico que marca cuando termina la capacidad normal de división de una célula.

En la Universidad de Rochester se ha descubierto que algunos de estos genes cooperan entre sí para transformar células normales en malignas, por eso se les conoce ahora como "genes de respuesta cooperativa" ${ }^{48}$ El gen conocido como Ras, de una familia de genes (K-Ras. H-Ras- N-Ras, etc.), su activación normal es causa de crecimiento, buena diferenciación y división celular. Estos genes, a su vez, producen un grupo de proteínas (se han descrito más de 100), que regulan en diversas formas, el comportamiento de la célula sana donde se encuentren. Las mutaciones de estos genes alteran algunas proteínas, estas se vuelven anómalas y causan mala división celular. De esta forma, son capaces de ayudar a producir diferentes cánceres como sarcomas, neuroblastomas, y otros. Al parecer, una tercera parte de todos los cánceres tienen este gen lesionado. ${ }^{49,50}$

Existen además, genes que regulan o frenan la división celular normal. Estos genes normalmente regulan la división de las diferentes células en los diversos órganos y "saben" cuántas veces normalmente deben dividirse, son los que causan la llamada apoptosis o muerte de las células viejas o enfermas en nuestro organismo, inclusive destruyen células malignizadas. $^{40,51,52}$ De hecho, como señala G. Klein ${ }^{53}$ la apoptosis es uno de los mecanismos de defensa de nuestro organismo contra la aparición de células tumorales. Los telómeros formados por ADN y situados en cada extremo de los cromosomas, son los encargados de la integridad del $\mathrm{ADN}$, impidiendo que pierda trozos cuando se replica y en cada división celular forman un anillo que se va reduciendo conforme se divide la célula normalmente y llega un momento que ese anillo impide a la célula, dividirse más. Una enzima, la telomerasa formada por ARN y una proteína del protoplasma, ayudan a los telómeros en esta acción.

Paradoja 6. Conforme los telómeros de los extremos de los cromosomas se van reduciendo, las células dejan de reproducirse y mueren. En el caso de las células cancerosas, la actividad de la enzima telomerasa es mayor y mantiene activos los telómeros y por eso se dividen sin parar. Uno de los genes mejor conocidos de este tipo y que cuando está sano impiden la división celular en exceso, es el p53, una de sus proteínas repara y estabiliza el ADN lesionado. Lamentablemente, se ha encontrado que más del $50 \%$ de los tumores del hombre tienen mutaciones de este gen p53. ${ }^{53}$

No obstante, algunos tumores escapan a este mecanismo de la apoptosis debido a que producen moléculas antiapoptosis, llamadas BCL2-BAX-BAK-APFI y otros. Pero no todas las células tumorales escapan a la apoptosis, muchas son destruidas por este mecanismo y así se evitan cánceres. Se ha señalado que existe otra forma de apoptosis contra las células tumorales, llamada anoiks, debido a que células normales adyacentes producen un factor inhibidor de crecimiento que mata a las células enfermas. ${ }^{50}$

Finalmente, hay genes reparadores de lesiones, que permanentemente y minuto a minuto, están reparando lesiones del ADN o de las células. Ahora bien, si paradójicamente la división celular es muy acelerada o el gen está lesionado, se cansan y puede desarrollarse una célula maligna. Se dice que los genes de las stem cells de algunos tejidos participan en este proceso. ${ }^{14}$

Paradoja 7. ¡Y siguen las paradojas! Se puede decir que los genes responsables de la aparición de una neoplasia son los siguientes

1) Genes que causan cáncer por su presencia como es el caso de los genes que normalmente regulan el crecimiento y división celular ya citados, y que si son lesionados, se califican como genes oncógenos, como es el ejemplo de los genes calificados como $C-M Y C$ que contribuyen a dar linfomas, o los llamados RAF que se ven en el cáncer del estómago. O los TRK en las neoplasias tiroideas, o el K-RAS en pulmón y otros. $^{26,27,30,49}$ Muchos de ellos tienen la habilidad de inducir a la formación de vasos sanguíneos para oxigenar el tumor, proceso conocido como angiogenesis. ${ }^{54}$ Algunos tumores en que participan estos genes, secretan factores que impiden a los macrófagos del área alertar al sistema inmune para reconocer y atacar la lesión. Al parecer eso sucede en el cáncer gástrico. ${ }^{47} \mathrm{El}$ problema es que hasta hace pocos años se sabía que existían 4 genes, encógenos y hoy se conocen $120 .^{27}$

2) Hay genes que causan cáncer por su ausencia por ejemplo, los genes normales que suprimen el crecimiento y la división celular normal ya vistos y conocidos como P53 -APC - RB - RSK4 y otros..$^{30,53}$ Hasta hace poco, se conocían solo dos y hoy se han descrito 20 o más de estos genes supresores, que funcionan como ya vimos regulando las veces que una célula normal se divide según el órgano y cuando la célula envejece o se lesiona le provocan la muerte. $^{27}$ Lamentablemente, pueden mutar debido a carcinógenos adquiridos y entonces no frenan a los genes de división, que si ya están mutados, actúan como encógenos provocando una división anómala y acelerada. Cinco o seis sistemas regulatorios sanos deben afectarse para que una célula se vuelva cancerosa. ${ }^{27}$ Douglas Easton de la Universidad de Cambridge cree que aparte de los genes conocidos BRCA1 y BRCA2 que causan cáncer de la mama 
si están mutados, hay por lo menos 100 genes más de baja penetración que ayudan a dar estos tumores de la mama. ${ }^{16,55}$

Andrew Futrel ${ }^{15}$ señala que han encontrado mutaciones somáticas del gen TP53 en la mayoría de los cáncer es del colon. Richard Wilson de la Universidad de Washington señala que se había descubierto 26 genes del cáncer de pulmón, aparte de los cinco ya conocidos. Además, han demostrado que la tasa de variaciones genéticas es diferente de un cáncer a otro, debido a defectos en la reparación del $\mathrm{ADN}$ de las células. ${ }^{35} \mathrm{En}$ el caso de los niños de madres enfermas sin un gen específico de una región del cromosoma 13, llamado gen $\mathrm{rB}$ (los dos alelos que limitan la división celular) muta, se produce una proteína anómala, da lugar a la aparición de un retinoblastoma heredado. ${ }^{26,31}$ por lo tanto, se requiere, en la mayoría de los casos, para que se produzca un cáncer que aparezcan genes oncógenos (activados) con múltiples mutaciones a través de los años en la mayoría de los casos; no logren ser reparadas las lesiones de esos genes o células en etapa preoncógena; también se lesionen genes frenadores de la división celular normal, y entonces los oncógenos la conviertan en imparable y permanente. ${ }^{28,56}$

Paradoja 8. No sabemos con certeza “¿por qué?” una célula normal se vuelve cancerosa bajo determinados estímulos, mientras que otra no. Para ser más claros. No sabemos con seguridad “¿por qué?” en condiciones similares unas personas desarrollan un cáncer y otras no, aunque estamos comenzando a comprender esto. ${ }^{27,56,57}$ En la caja de texto 2 se mencionan los mecanismos que participan para evitar que aparezca un cáncer y otros que más bien favorecen su aparición. A continuación algunos ejemplos

Cáncer del pulmón, cientos de millones de personas fuman por años y sin embargo, relativamente solo unos pocos sufren de esa enfermedad. Aquí se junta el factor de riesgo con la resistencia inmunológica de cada individuo. Se han descubierto hasta 26 genes, aparte de los cinco ya conocidos como: tP53, Ktas, Stki, Egfr, que al alterarse coadyuvan a dar un cáncer. Además, se han reportado hasta 29 mil mutaciones en las células de un adenocarcinoma.

Leucemias de los granjeros, miles de agricultores en los Estados Unidos (y por supuesto en otros países) se exponen a pesticidas e insecticidas y sin embargo, son pocos los que sufren de una leucemia debido a lesiones de los cromosomas 5 y $7 .^{6}$

Cáncer de cervix, millones de mujeres se infectan al tener relaciones sexuales con alguna cepa del virus del papiloma humano, que se señala como el principal factor para producir cáncer del cuello de la matriz. En el $90 \%$ no se producen lesiones o estas fueron reparadas debido a que se desarrolló inmunidad contra ese virus. Solo un $10 \%$ requieren tratamiento, si las lesiones displásicas persisten por dos años o progresan, puede aparecer un cáncer.

Cáncer del estómago. Voy a citarlo en forma más amplia debido a que constituye la primera causa de muerte por cáncer en Costa Rica, y es el tercero en frecuencia ${ }^{5}$ aunque al igual que en los países desarrollados, los cambios hacia una mejor alimentación de la población, el tratamiento del Helicobacter pylori y el diagnóstico temprano, han disminuido la frecuencia y la mortalidad. Este tumor tiene un origen multifactorial, ${ }^{4}$ pero se considera que la causa principal es la infección por la bacteria Helicobacter Pylori, principal agente capaz de producirlo. ${ }^{59,60}$ De hecho más del $50 \%$ de la población mundial tiene o ha tenido esta infección en su estómago y suele comenzar desde niño. En los países subdesarrollados llega al $80 \%$.

Lo paradójico es como dice la Dra. Eliette Touati, del Instituto Pasteur de París, especialista en este tema, que la bacteria se mantiene en el estómago sin producir síntomas o provocando daños mínimos a la mucosa, pero en un 3\% puede provocar lesiones más serias en la mucosa y con el tiempo, si no son reparadas pueden dar, en algunos casos, un cáncer. ${ }^{61}$ La OMS lo ha considerado un agente carcinógeno tipo I o de primera línea. Aunque no se ha demostrado per se, que cause cáncer, sus lesiones en la mucosa sí pueden darlo. ${ }^{41,62}$ Cuando Marshall y Warren la descubrieron en el año 1982 (años después les dieron el Premio Nobel), demostraron que provocaba diversas lesiones en la mucosa gástrica, entre ellas, gastritis crónica atrófica, metaplasia intestinal, y ulceras pépticas y finalmente, en algunos casos, cáncer. Esta bacteria contribuye a causar el principal cáncer histológicamente hablando, el adenocarcinoma, que se divide en intestinal y difuso según Lauren., ${ }^{4,63}$ Otras causas se contribuyen a producir este tipo de tumor se mencionan en la caja de texto 3 .

\section{Paradojas en relación con el cáncer gástrico}

Paradoja 1. Consiste en que la atrofia de la mucosa gástrica que produce hipoclorhidria, elimina la barrera normal defensiva de la acidez gástrica y eso facilita que otras bacterias colonicen la mucosa gástrica lesionada (eliminando ellas al Helicobacter pylori) y son capaces de dar compuestos nitrogenados con capacidad mutagénica, ejemplos: Clostridium difficile, E. Coli. ${ }^{64}$

Paradoja 2. Hay Helicobacter pylori malos y buenos. Rudolf Virchow en 1883 había señalado que el cáncer se origina en sitios de inflamación crónica. Ahora sabemos que hay cepas de Helicobacter pylori malas por poseer varios genes (CagA-PAI-VAC As, y otros.), que producen proteínas y citoquinas vacuolizantes que destruyen el epitelio mucoso gástrico y desencadenan la serie de lesiones que terminan dando cáncer. Inicialmente, producen una gastritis crónica superficial, luego en un $40 \%$ pasa a una gastritis atrófica. Después de 20 o hasta 50 años de padecer esto, aparece una metaplasia intestinal. Ambas lesiones pueden pasar a dar displasia leve, luego moderada y finalmente severa y de ahí, algunos casos pasan a dar cáncer. You, Wei Cheng y colaboradores $^{65}$ señalan que en un área de China la prevalencia de gastritis crónica en la población adulta, fue de un $20 \%$, de metaplasia intestinal $50 \%$, y displasia de un $20 \%$ y que, el riesgo de contraer un cáncer gástrico se incrementa con la severidad de las lesiones provocadas por el Helicobacter pylori. Se conoce que algunas de las proteínas de esos genes malos, producen inmuno supresión local. Hay además, las llamada cepas buenas de Helicobacter 
Caja de texto 3. Otras causas que contribuyen a producir cáncer gástrico

1. Múltiples genes supresores de tumores se ha encontrado inactivados en pacientes con cáncer gástrico, como los del grupo tp53, APC- DCC.

2. Las dietas deficientes en frutas y verduras frescas que contienen vitaminas y minerales que actúan como antioxidantes, bloqueando radicales libres a nivel de la mucosa lesionada. ${ }^{3}$

3. La ingesta de alimentos contaminados con nitratos que dan nitrosaminas en el estómago un carcinógeno. $^{3}$

4. Abuso en comer alimentos muy salados y ahumados como carne al carbón que dan gastritis. ${ }^{6}$

5. Abuso en fumado y beber licor.

6. Fallas en el sistema inmunológico defensivo celular.

7. La existencia de pólipos adenomatosos, en especial, vellosos de más de 2 centímetros de diámetro.

8. Una historia familiar de cáncer gástrico por susceptibilidad genética aumenta la posibilidad de que aparezca. ${ }^{48}$

pylori, que no producen toxinas por no tener el gen codificante, y por ello, no provocan cáncer, se está en espera de ver cuál es su papel. En una misma persona infectada puede haber varias cepas diferentes.

Paradoja 3. El H. pylori aunque vive en medio ácido, no le gusta el exceso de acidez del síndrome de Zollinguer y Ellison, debido a tumores funcionales pancreáticos que provocan úlceras pépticas duodeno-gástricas. Pero tampoco le agrada la falta de acidez, como la que existe en la gastritis crónica atrófica de la Anemia Perniciosa y no influye en la aparición de cáncer gástrico en estos casos. No ejerce predominio en la aparición del adenocarcinoma cardial y del esófago bajo, que tiene otras causas como el reflujo ácido gástrico que provoca el llamado esófago de Barrett donde suelen nacer estos cánceres. ${ }^{39,41,59}$

No suele verse en el cáncer que aparece 20 años después en una gastroenteroanastomosis, donde el reflujo de bilis hacia el estómago causa una gastritis alcalina. Produce un tumor, el Linfoma MALT, del tejido linfoide de la pared gástrica totalmente diferente al adenocarcinoma. En algunos casos de cáncer difuso del estómago no se le encuentra como factor de riesgo, en otros sí.

Paradoja 4. El empleo prolongado de bloqueadores de la acidez por meses años (inhibidores de la bomba de protones) como en el caso del reflujo esofágico o úlceras pépticas rebeldes, puede dar lugar a hipergastrinemia, gastritis atrófica y carcinoides y hasta cáncer. ${ }^{64,66}$

Paradoja 5. El estómago produce 2 hormonas que se relacionan con estimular o inhibir el apetito. El Leptin o Leptina que le avisa al cerebro y este dicta "no más comer" y la Ghrelin o Grelina que abre el apetito (da hambre). Ahora bien, si se irradica el Helicobacter pylori, esta última hormona la Grelina tiende a aumentar en la sangre y se abre en exceso el apetito de esas personas; entonces, comen más, aumentan de peso y de todos es sabido que la obesidad es un factor de riesgo para sufrir de cáncer y cardiopatías. ${ }^{67}$ Por cierto, ya un $20 \%$ de los Helicobacter pylori son resistentes a los tratamientos habituales.

\section{Referencias}

1. WHO. World Cancer day 2009. World Health Organization. En: www. who.int/cancer/en/ Consultado 29 de agosto de 2009.

2. Instituto Nacional de Estadísticas y Censos. Causas de mortalidad en Costa Rica en el año 2006. INEC. 2006.San José. Costa Rica. Estadísticas Vitales.

3. International Agency for Research on Cancer. (2009) Facts and Figures of Cancer. World Health Organization. En. http://telescan.nki. nl/iarc.html pg 1-18 Consultado el 29 agosto de 2009

4. Mena F. Las bases moleculares del cáncer gástrico. Act Médic Costarric 2002; 2: 53-54.

5. Ministerio de Salud. Incidencia y mortalidad por cáncer en Costa Rica.www.ministeriodesalud.go.cr/memorias/memoria 2007. Consultado el 29 agosto de 2009.

6. Jaramillo J. El Cáncer. Tomo I. Editorial Universidad de Costa Rica, San José. 1999.

7. Alonso R, Szoztak J. Life on Earth. Scientific American 2009; 3: 38-45.

8. Pet Cancer registry. En: http://www.scienceonline.org/cgi/content/ short/297/ 5579/189b. Consultado el 23 de octubre de 2009

9. Emory University. Timeline of Cancer. Emory University En: www. cancerquest.org/. Consultado el 29 de agosto de 2009

10. Soares C. Origins of cancer. Scientific American 2009; $3: 62$.

11. Singh SK. Clarke ID. Identification of a cancer stem cell in human brain tumor. Cancer Research 2003; 63; 5821-5828.

12. Emory University. Cancer Stem Cell. En: www.cancerquest.org/ index. Consultado el 29 de agosto de 2009

13. Hernando E. Las células madres del cáncer. En www.elmundo.es/ elmundosalud/2007/03/ Consultado 02 de noviembre de 2009

14. Nombela C. Células madres, encrucijada biológica para la Medicina. Madrid, España. Ed. Edaf. 2007

15. Futreal A. A Census of Human Cancer Genes. Nature Reviews 2004; 4: $177-180$

16. Al-Haij et al. (2003). Prospective identification of tumorigenic breast cancer cell. Proceding National Academy of Science, USA. 100: 7; 3983-3988.

17. Bonnet D, Dick EJ. Human acute myeloid leukemia is organized as hierarchy that originates from primitive hematopoietic cell. Nature Medicine 1997; 3: 730-737.

18. O.Brien, Ca. Pollett A, Gallinguer S, Dick JE. A human cancer cell capable of initiating tumour growth in inmunodeficient mice. Nature 2007; 445: 1006-1010.

19. Un trabajo sobre las células madres del cáncer, desbarata la teoría más Extendida. En:http://www.elmundo.es/elmundosalud/2008/12/03/ oncologia/1228323871.html Consultado el 23 de octubre de 2009

20. National Cancer Institute. Cancer Facts. National Cancer Institute. EE.UU. En: Http://cancer.gov/ . Consultado el 29 agosto de 2009.

21. Alvarado E. Adenocarcinoma de pulmón con etiopatogenia asociada al cocinado con leña. Acta Médic Costarric 48; 2006 (Supl):25.

22. Enviromental Protection Agency. Evaluating pesticides for carcinogenic potetential. United States Enviromental Protection Agency, 2005. En: http//www.epa.gov/pesticides/healt/cancer Consultado el 29 de agosto de 2009 
23. Worsham MJ. Identifican 231 nuevos genes asociados con el cáncer de cabeza y cuello. En: http://es.globedia.com/identifican 231-genesasociados-cancer-cabeza-cuello Consultado el 23 de octubre de 2009

24. Navas M. Hallan genes de cáncer de la próstata. En: http://news.bbc. co.uk/hispanish/siecnce/newsid_7238000/7238948.stm . Consultado 23 de octubre de 2009

25. Emory University.The Role of Mutation in Cancer. En: www. cancerquest.org/index. Consultado el 12 octubre de 2009

26. Enciclopedia Britannica. Genes and Cancer. En Enciclopedia Británica, 2009. En: www.tirgan.com/genetics/genescancer.htm

27. Wayt Gibbs, W. Roots of Cancer. Scientific American 2003; 289:49-57.

28. Varmus, Harold. The Mechanics of Cancer. New York Academy of Science Magazine 2002; 6-7.

29. Emory University Mutation and Cancer. En: www.cancerquest.org/ index. Consultado el 12 octubre de 2009

30. Sporn M. Dichotomies in cancer research: some suggestion for new synthesis. Nature Clinical Practice Oncology 2006; 7: 364-373.

31. Wenstein BJ, Andrew K. Mechanisms of Diseases: oncogene addictiont A rationale for molecular targeting in cancer therapy. Nature Clinical Practice Oncology 2006; 3: 448-457.

32. Valerio M. El mapa del cáncer de colon y de mama desvela 200 genes con funciones diferentes. Universidad de John Hopkins. En:.http:// www.elmundo.es/el mundosalud/2006/09/07oncologia/1157641812. html. Consultado el 23 octubre de 2009

33. Emory University. Section Summary: Genetic Changes. En: www. cancerquest.org/index. Consultado el 12 octubre de 2009.

34. Jonkers J, Berns A. Oncogene addiction: sometimes a temporary slavery. Cancer Cell 2004; 6; 535-538.

35. Gonzales A. Descubiertos los 26 genes del cáncer de pulmón.

En: http://www.publico.es/ciencia/167301/adenocarcionoma/ cancerdepulmon/genoma/genes/Consultado el 23 de octubre de 2009

36. Loeb L, Loeb K, Anderson J. Multiple Mutations and Cancer. Proc Natl Acad Sci U S A 2003; 3; 776- 781.

37. IARC. (2005) Monographs on the evaluation of carcinogenic risk to humans. Lyon: International Agency for Research on cancer. 2005. En: http://monographs.iarca.fr/. Consultado el 29 de agosto de 2009

38. Partanen T, Monge P, Wesseling C. Causas y prevención del Cáncer Ocupacional. Acta Médic Costarric 2009; 51: 195-205.

39. Bouvard V. Baan, R, Straif, Kurt, et.al. A review of human carcinogensPart B: biological agents. WHO International Agency of Research on Cancer Monograph Working Group 2009; 430-431.

40. Campisi, J. Natural selection lacks the power to erase cancer from our species and, some scientists argue, may even have provided tools that helps tumor grow. Scientific American 2007; 53- 60.

41. WHO. A review of human carcinogenesis. PartB: biological agents. Word Health Organization. En: www.thelancet.com/oncology Consultado 29 de agosto de 2009.

42. Strehlow K. Modulation of antioxidant enzyme expression and function by estrogen. Circ Res 2003; 93:170-177.

43. Thibodeau P. In vitro pro-and antioxidant properties of estrogen. Journal Steroid Biochem Mol Biol 2002; 81: 227-236.

44. Hoeijmakers J.H. DNA damage, aging, and cancer. N Engl J Med 2009; 8. 1475-1485.

45. How Do abnormal Genes cause Cancer?. BreastCancer.Org En:www. breastcancer.org/risk/Genetic/abnrml/genes.jsp. 2009. Consultado el 23 de octubre 2009
46. Carmichael M. Un retrato cambiante del ADN. Newsweek en Español 2007; 17:38-40

47. University of Virginia. How Genes Cause Cancer. En: www. healthsystem.virginia. Consultado 19 setiembre de 2009

48. Beyret, P. Descubren genes promotores del cáncer. En: http://www. biotecnologica.com/descubren-genes-promotores-del-cancer/ Consultado el 23 de octubre 2009

49. Jackson EL, Willis N, Mercer K, Bronson RT, Crowley D, Montoya R. Analisis of lung tumor initiation and progresion using condicional expresión of oncogenic K-ras. Genes Dev 2001; 15: 3243-3248

50. Journal of the American Chemical Society. Nuevo agente elimina varias enzimas en vías del cáncer. En la edición de Abril del 2009 del Journal. Citado en Hospi Medica 2009; 5: 8-9.

51. Campisi,J. Suppressing Cancer. The Importance of being senscent. Science 2005; 308: 886.

52. Ker JF. Apoptosis. Its significance in cancer and cancer therapy. Cancer 1994; 7: 2013-2026.

53. Klein G. Cancer, apoptosis and nonimmune surveillance. Cell Death and Diferentiation. Nature 2004; 11: 13-17.

54. Emory University. Angiogenesis and Metastasis. En: www. cancerquest.org/index. Consultado el 29 agosto de 2009

55. Nuevos genes candidatos en el complejo puzzle del cáncer de la mama. En: hhtp://www.elmundo.es/elmundosalud/ 2009/03/27/ oncologia/1238175188.html Consultado el 23 de octubre de 2009

56. Zimmer C. El acertijo de los genes. Newsweek en español. Extractos del Libro del autor "The New Science of Life". 2009;23: 38-40.

57. Un consorcio internacional para descifrar los genes del cáncer. En: http://www.elmundo.es/elmundosalud/2008/05/05/ oncologia/1209972447.html Consultado el 23 de octubre de 2009

58. Emory University. The Immune System.- The innate and the Acquired. En: www.cancerquest.org/index. Consultado el 12 octubre de 2009.

59. Garza T. Helicobacter Pylori y cáncer gástrico. Boletín Oncológico. En: www.boloncol.com/boletin-5/helicobacter-pylori-y-cancergastrico.html Consultado el 23 de agosto de 2009

60. IARC. Infection with Helicobacter pylori. International Agency for Research on Cancer. World Health Organization.

61. Touati, Eliette. El Cáncer Gástrico se puede prevenir. De la Conferencia que dio en el INISA-UCR. La Nación. 17 Octubre 2009, 28 A.

62. Aravena E, Edmundo. Helicobacter pylori y cáncer gástrico. Gastroenterología Latinoamericana 2007;18:129-132.

63. Lauren P. The two histological main types of gastric carcinoma: diffuse and so called intestinal type carcinoma. Acta Path Microbiol Scan 1965; 64: 32-49.

64. Tauseef Alf, Neil D, Tirney W. Long-termk Safety Concerns with the Proton Pump Inhibitors. Am J Med 2009; 122: 896-903.

65. You, Wei Cheng, LI Ji You. Etiology and prevention of gastric cancer; a population study in a high risk area of China. Chinese Journal of Digestive Diseases 2005; 6:149-154.

66. Poulsen AH, Christensen S, McLaughlin JK, Thpmsen RW, Serensen HT, Olsen JH. Proton pupm inhibitors and risk of gastric cancer: a population-based cohort study. Br J Cancer 2009;100:1503-7.

67. Consumer Eroski. Control de una hormona del estómago facilita el Adelgazamiento. La grelina. En: www.consumer.es/web/es/salud/ Consultado el 29 de agosto de 2009. 